\title{
COMMENTS
}

\section{Union Liability Under the Age Discrimination in Employment Act}

\author{
Karen L. Peckं
}

In 1967, Congress passed the Age Discrimination in Employment Act ("ADEA") ${ }^{2}$ to help secure employment opportunities for the elderly. Though by its terms the Act clearly prohibits unions as well as employers from discriminating on the basis of age, it does not explicitly provide that unions may be held liable for damages. Federal courts have diverged in determining union liability under the Act. Some have denied liability altogether, construing the enforcement section of the ADEA to incorporate the substantive provision in the Fair Labor Standards Act ("FLSA") ${ }^{2}$ that limits liability to employers. ${ }^{3}$ Under a second approach, courts have concentrated on the broad language in the ADEA authorizing courts to "grant such legal or equitable relief as may be appropriate to effectuate the purposes of [the Act]."" Reasoning that liability for damages will deter union discrimination and thus "effectuate" the goals of the Act, these courts have imposed monetary

$\dagger$ B.A. 1984, Florida State University; J.D. 1989, The University of Chicago.

129 USC $\$ 621$ et seq (1982).

229 USC \& 201, 216(b) (1982).

3 This first approach to the ADEA is illustrated by Air Line Pilots Association $v$ Trans World Airlines, 713 F2d 940 (2d Cir 1983), and Neuman v Northwest Airlines, 28 FEP Cases (BNA) 1488 (ND Ill 1982). In ALPA v TWA, the union and employer negotiated an age-based promotion policy that discriminated against older pilots. The court found that the union had violated the ADEA, but refused to hold it liable for monetary damages. 713 F2d at 957. In Neuman, the plaintiff alleged that the union had participated in negotiating a mandatory retirement provision that violated the ADEA. The court granted the union's motion for summary judgment, expressly disregarding the broad remedial language in the ADEA. 28 FEP Cases (BNA) at $1489 \mathrm{n} 1$.

+ 29 USC $\S 626(b)$. 


\section{liability on unions violating the ADEA. ${ }^{5}$}

Neither of these two approaches is a proper treatment of union liability under the ADEA. The first employs a wooden interpretation of the Act's enforcement provision, disregarding language in the same section of the Act. It is a piece-meal approach, lacking a coherent, comprehensive resolution of the Act's substantive and enforcement provisions. Indeed, this interpretation hinders the express purpose of the Act: protecting workers from age discrimination. Courts taking the second approach do attempt a purposive interpretation of the ADEA, but their analyses of the statute remain superficial. In particular, these courts provide no guidelines for limiting judicial discretion in the selection of remedies.

This comment develops a doctrinal basis for assessing backpay damages against unions that have violated the ADEA. Section I discusses the support that the language and history of the Act furnish for imposing monetary liability on unions. Section II analyzes the language, history, and case law of the FLSA, on which the enforcement provisions of the ADEA are based. This section also discusses federal court decisions interpreting the Equal Pay Act of 1963 ("EPA"), ${ }^{6}$ another amendment to the FLSA proscribing certain discriminatory conduct by unions. Section III examines the evolving federal labor law doctrine of the duty of fair representation, demonstrating that courts treat age discrimination by unions less seriously under the ADEA than under labor law. Section IV proposes construing the ADEA to allow backpay awards against unions in private enforcement actions.

\section{The Statutory Framework of the ADEA}

\section{A. The Language of the Statute}

Congress had several objectives in enacting the ADEA, among them promoting the employment of older persons based on their ability alone, prohibiting arbitrary age discrimination in employ-

- Cases illustrative of this second approach are U.S. Equal Employment Opportunity Commission v Air Line Pilots Assn., 489 F Supp 1003 (D Minn 1980), and Boiero v Cuyahoga County Library Union, 1988 US Dist LEXIS 9266 (N D Ohio). The union in $E E O C$ v $A L P A$ negotiated a contract provision giving pilots nearing retirement age less favorable vacation benefits than younger pilots. The court ruled that the union had violated the ADEA and held it liable for lost compensation. 489 F Supp at 1009. In Boiero, the plaintiff alleged that the union had refused to take her grievance to arbitration because of her age and national origin. The union moved for summary judgment on the ground that it could not be held liable under the ADEA. The court disagreed and denied the motion. 1988 US Dist LEXIS 9266 at 9-10.

b 29 USC \& 206(d) (1982). 
ment, and coordinating the efforts of employers and workers to meet age-related employment problems. ${ }^{7}$ Generally, the Act prohibits employers, employment agencies, and labor organizations from discriminating on the basis of age against persons over forty, ${ }^{8}$ unless the differential treatment fits one of several statutory exemptions. ${ }^{\circ}$ Labor unions are specifically prohibited from engaging in certain discriminatory conduct. They cannot exclude an individual from union membership because of her age. They cannot classify or segregate members on the basis of age in a manner that denies workers employment opportunities. And finally, a union cannot "cause or attempt to cause" an employer to discriminate against an employee on the basis of her age. ${ }^{10}$ In drafting the ADEA, Congress borrowed language from a variety of statutes. The result was a "hybrid" statute, with substantive provisions nearly identical to some in Title VII ${ }^{11}$ and enforcement provisions combining components of Title VII and the FLSA. ${ }^{12}$ It is the ADEA's relationship with the FLSA that has caused courts special trouble in determining union liability.

Congress stipulated that the Act be enforced "in accordance with the powers, remedies, and procedures" of selected sections of the FLSA. ${ }^{13}$ However, Congress significantly modified the remedial framework of the FLSA to suit what it regarded as problems peculiar to age discrimination. Believing that age discrimination arose less from invidious prejudice than from ignorance of older workers' capabilities and a societal emphasis on youth, Congress made conciliation and education the preferred means of enforcement. ${ }^{14}$

729 USC \& 621(b).

- 29 USC \& 631(a).

- 29 USC $\S \S 623(\mathrm{f})(1)-(3), 630(\mathrm{~b})$. Exemptions include cases where age is a bona fide occupational qualification or is a component of a bona fide seniority system or pension plan.

10 29 USC $\S 623(c)(3)$.

142 USC \$ 2000 e et seq (1982). Compare Title VII's provisions forbidding discrimination on the basis of race, color, religion, sex, or national origin at 42 USC $\S 2000 \mathrm{e}-2$ (c) with the ADEA provisions at 29 USC \& 623(c).

12 Section 626(b) of the ADEA provides that the Act "shall be enforced in accordance with the powers, remedies, and procedures provided in sections 11 (b), 16 (except for subsection (a) thereof), and 17 of the [FLSA], as amended ... and subsection (c) of [section 626 of the ADEA]." The section also contains language comparable to Title VII's provisions at 42 USC $\S 2000 \mathrm{e}-5(\mathrm{~g})$, providing that in ADEA actions a court "shall have jurisdiction to grant such legal or equitable relief as may be appropriate to effectuate the purposes of this [statute], including without limitation judgments compelling employment, reinstatement or promotion, or enforcing the liability for amounts deemed to be unpaid minimum wages or unpaid overtime compensation. ..."

13 See note 12.

14 Department of Labor, The Older American Worker: Age Discrimination in Employment 1-2 (1965), reprinted in Hearings on HR 10634 and Similar Bills before the Select 
Thus, like the FLSA, the ADEA has a dual enforcement system that allows both the Secretary of Labor ${ }^{15}$ and private litigants to bring actions under the Act. Unlike the FLSA, however, the ADEA requires private litigants to notify the Secretary 60 days before initiating the lawsuit. ${ }^{16}$ This notification gives the Secretary the opportunity to eliminate the discrimination through "conciliation, conference, and persuasion."17

Section 7(b) of the ADEA, like the FLSA provisions, states that "amounts owing" to a person as a result of a violation of the Act are deemed to be unpaid minimum wages or overtime compensation. ${ }^{18}$ However, the ADEA enforcement scheme employs a modified version of the FLSA's liquidated damages provision. Under the FLSA, liquidated damages are granted as a matter of right once a violation is shown. ${ }^{19}$ Under the ADEA, liquidated damages are available only for "willful violations." 20 This difference reflects the statutes' divergent purposes. Liquidated damages are given under the FLSA to ensure that plaintiffs are fully compensated in cases where damages are not easily calculated. ${ }^{21}$ Under the ADEA, however, liquidated damages have taken on a punitive character because of the elimination of criminal penalties. ${ }^{22}$

Two other modifications of the FLSA are notable. First, as just noted, Congress chose not to incorporate the criminal penalties of the FLSA into the ADEA. Apparently, Congress wanted to encourage employers and unions to rectify age discrimination problems voluntarily and believed that conciliatory actions would be more likely without the threat of criminal sanctions. ${ }^{23}$

Second, and of particular significance, Congress included the

Subcommittee on Labor of the House Committee on Education and Labor, 89th Cong, 1st Sess 56 (remarks of Rep O'Hara); id at 57-58 (remarks of Rep Hathaway and Sen Javits).

${ }^{16}$ Responsibility for enforcing the ADEA was originally given to the Secretary of Labor, but was transferred to the Equal Employment Opportunity Commission ("EEOC") by the Reorganization Plan Number 1 of 1978, § 2, 43 Fed Reg 19807 (1978). This comment refers to the Secretary and the EEOC interchangeably.

18 29 USC § 626(b).

17 Id.

${ }^{18}$ Id (ADEA) and 29 USC \& 216 (b) (FLSA).

1929 USC § 216 (b).

${ }^{20} 29$ USC § 626 (b).

${ }^{21}$ See Brooklyn Savings Bank v O'Neil, 324 US 697, 707 (1945).

${ }^{22}$ See Trans World Airlines $v$ Thurston, 469 US 111, 125 (1985). Senator Javits, the primary sponsor of the ADEA, suggested that the bill include a liquidated damages remedy as a substitute for criminal penalties to punish willful offenders. Id.

${ }^{29}$ Age Discrimination in Employment Act of 1967, Hearings on S 830, S 788 before the Subcommittee on Labor of the Senate Committee on Labor and Public Welfare, 90th Cong, 1st Sess 24-25 (1967) (remarks of Sen Javits). 
following provision in $\S 7$ of the ADEA: "In any action brought to enforce this [Act] the court shall have jurisdiction to grant such legal or equitable relief as may be appropriate to effectuate the purposes of [the statute]. . . ."24 This comment will argue that this provision authorizes the courts to choose among the full range of traditional remedies in redressing a particular ADEA violation. Congress recognized that the remedial provisions of the FLSA were not perfectly suited to the age discrimination context, and thus gave courts the flexibility to address any disparities that might arise. $^{25}$

A final important difference between the FLSA and the ADEA enforcement provisions involves the entities subject to liability under each. Section 16(b) of the FLSA states that any employer found in violation of the statute will be held liable; ${ }^{26}$ labor organizations are explicitly excluded from the statute's definition of employer. ${ }^{27}$ In contrast, $\S 7$ (b) of the ADEA contains no express limitation of liability to employers. But because that provision states that the Act shall be enforced in accordance with the "powers, remedies, and procedures" of the FLSA, ${ }^{28}$ courts have disagreed over whether the ADEA's remedial provisions do in fact apply to unions. ${ }^{29}$

The next section explores the legislative history of the ADEA to determine whether the historical record can resolve the uncertainty regarding application of the ADEA to labor unions.

\section{B. The Legislative History of the ADEA}

The legislative history of the ADEA does not conclusively resolve the question of union liability under the Act. It shows, however, that the aspects of the Act suggestive of a Congressional intent to bar union liability were the result, not of purposeful considerations of the merits of liability, but of practical concerns for administration of the Act as a whole.

Congress began considering the problem of age discrimination

24 29 USC § 626(b).

${ }^{2 s}$ See Koyen v Consolidated Edison Co. of New York, Inc., 560 F Supp 1161, 1168 (S D NY 1983) (construing ADEA to allow courts to fashion remedies beyond those authorized in the FLSA in order to fully compensate plaintiff for economic losses). See also J. Hardin Marion, Legal and Equitable Remedies Under the Age Discrimination in Employment Act, 45 Md L Rev 298, 324 (1986).

2829 USC $\$ 216(\mathrm{~b})$.

2729 USC \& $203(\mathrm{~d})$.

${ }^{28} 29$ USC $\S 626(\mathrm{~b})$.

29 See notes 3 and 5 . 
in employment while deliberating Title VII of the Civil Rights Act of $1964,{ }^{30}$ when several legislators advocated including age discrimination within the compass of the Act. ${ }^{31}$ Various practical concerns blocked inclusion, ${ }^{32}$ but in Title VII Congress mandated that the Department of Labor study the "factors which might tend to result in discrimination in employment because of age and of the consequences of such discrimination on the economy and individuals affected." ${ }^{33}$ In 1965 the Labor Department study was released. ${ }^{34}$ It concluded that age discrimination was serious and widespread, and that non-statutory methods of dealing with it had been ineffectual. It confirmed that age discrimination resulted from general misunderstandings about the abilities of older workers rather than from invidious prejudice. And it called for federal legislation prohibiting arbitrary age discrimination. ${ }^{35}$

On the heels of the Labor Department study, members of Congress and the executive branch introduced several bills aimed at age discrimination in employment. The Johnson Administration's proposal ${ }^{36}$ included an enforcement scheme similar to that established by the National Labor Relations Act ("NLRA");"37 it would have created a new administrative agency within the Department of Labor possessing prosecutorial and quasi-judicial powers. A competitor bill was Senate bill $788,{ }^{38}$ sponsored by Senator Javits, which proposed to address age discrimination by amending

so 42 USC $\S 2000 \mathrm{e}$ et seq.

${ }^{31}$ HR 10144, 87th Cong, 2d Sess (February 21, 1962) included a provision specifically outlawing age discrimination in employment. In reporting the bill, the House Committee on Education and Labor noted that "[ $t]$ he committee sees no reason to treat such arbitrary denial [on the basis of age] in any substantially different fashion from other employment discrimination." Equal Employment Opportunity Act of 1962, HR Rep No 87-1370, 87th Cong, 2d Sess 7 (1962).

${ }^{32}$ Some proponents of Title VII feared that inclusion of age discrimination would hinder passage of the bill. HR Rep No 87-1370 at 17 (cited in note 31) (supplemental views of members of the House Labor Committee). They argued that the EEOC, created to administer Title VII, could not adequately handle all types of discrimination cases, and that a prohibition on age discrimination would consequently be underenforced. Id at 18 (statement of Herbert Hill, NAACP). Other Title VII supporters claimed that age discrimination had been insufficiently studied and that any legislation addressing it would be premature. Equal Employment Opportunity Commission, Legislative History of Titles VII and XI of the Civil Rights Act of 1964 at 3167 (1968) (remarks of Rep Celler); id at 3169 (remarks of Rep Waggoner).

${ }^{33}$ The Civil Rights Act of 1964, § 715, Pub L No 88-352, 78 Stat 241, 265 (1964).

34 Department of Labor, The Older American Worker: Age Discrimination in Employment (1965) (cited in note 14).

${ }^{35}$ Id at $225-26$.

${ }^{36} \mathrm{~S} 830$, 90th Cong, 1st Sess (February 3, 1967).

${ }^{37} 29$ USC \$\$ 151-169 (1982).

${ }^{38}$ S 788, 90th Cong, 1st Sess (February 1, 1967). 
the FLSA. This bill gave enforcement powers to the Wage and Hour Division of the Department of Labor, the section already responsible for administering the Equal Pay Act. ${ }^{39}$

In 1967, S 788 was passed as the Age Discrimination in Employment Act. Several factors account for its success, nearly all administrative. ADEA placing the responsibility of enforcing the Act in the hands of an established agency saved Congress the burden of creating an entirely new bureaucracy. The drafters also believed that industry compliance would be easier and more likely, since employers and employees were already familiar with the procedures of the Wage and Hour Division. ${ }^{40}$ The bill provided a judicial forum for age discrimination claims. Supporters of the bill had feared that an administrative proceeding might not guarantee an impartial determination of liability, especially when the agency was also exercising prosecutorial powers. ${ }^{41}$ Finally, the bill bypassed the EEOC. Senator Javits, the primary sponsor of $\mathbf{S} 788$, had noted that the Commission was years behind in disposing of its docket, ${ }^{42}$ and was concerned that the long delays would be particularly harmful to the claims of older workers. In addition, some supporters of the bill stated that age discrimination required unique expertise, distinct from that required by the other forms of discrimination with which the EEOC was familiar. ${ }^{43}$

The legislative history of the ADEA yields no express reference to holding unions liable for damages. In adopting $S 788$ over its competitors, Congress did reject proposals that expressly held unions liable for damages for age discrimination. ${ }^{44}$ But the bill's

39 Another proposed age discrimination bill was patterned on Title VII and would have given the EEOC the power to enforce the age discrimination prohibitions. HR 9338, 89th Cong, 1st Sess (August 25, 1965). See Hearings on HR 10634 and Similar Bills before the Select Subcommittee on Labor of the House Committee on Education and Labor, 89th Cong, 1st Sess 5 (1965).

${ }^{10}$ Age Discrimination in Employment Act of 1967, Hearings on S 830 and S 788 before Senate Committee on Labor and Public Welfare, 90th Cong, 1st Sess 24 (1967) (statement of Sen Javits); id at 96 (statement of Andrew J. Briemiller, AFL-CIO).

61 Id at 323-24 (statement of National Association of Manufacturers).

12113 Cong Rec 7076 (March 16, 1967) (statement of Sen Javits).

${ }^{13}$ Hearings on HR 10634 and Similar Bills, 89th Cong, 1st Sess at 56 (cited in note 14) (statement of Rep O'Hara). See also 113 Cong Rec 34747 (December 4, 1967) (remarks of Rep Dent). The agency chosen to enforce the ADEA, the Wage and Hour Division, was only familiar with sex discrimination, so the validity of the "expertise" rationale is questionable.

"Secretary of Labor W. Willard Wirtz indicated that unions, employment agencies, and employers could all be held liable for damages under the administration's bill ( $\mathrm{S} 830$ / HR 4221). Age Discrimination in Employment, Hearings on HR 3651, HR 3768, and HR 4221 before the House Committee on Education and Labor, General Subcommittee on Labor, 90th Cong, 1st Sess at 12 (1967) (remarks of Secretary of Labor W. Willard Wirtz). See also HR 9338, 89th Cong, 1st Sess (cited in note 14). 
language leaves no doubt that Congress regarded unions as a part of the age discrimination problem. Indeed, Congress rejected the testimony of several union officials who had urged exclusion of unions from the substantive provisions of the Act as well. ${ }^{45}$

The legislative history of the ADEA shows that when Congress adopted the FLSA as a model for the ADEA's remedial provisions, it did not weigh the different purposes of the two acts, or the consequences of selective incorporation of FLSA provisions. Rather, Congress was concerned with creating a remedial scheme that would be efficient and easy to administer, and the FLSA satisfied both of these requirements. Thus, one cannot conclude that in choosing the FLSA's remedial provisions, Congress meant to incorporate all the policies and practices embodied in the FLSA. Indeed, the next section will show that such a conclusion would be mistaken, since the drafters of the ADEA had a much less benign view of unions than the legislators who drafted the FLSA twenty years before.

\section{INTERPRETATION OF THE FLSA}

Courts refusing to impose monetary liability on unions that have violated the ADEA generally base their decision on the Act's incorporation of the remedial provisions of the FLSA. ${ }^{46}$ Since the FLSA's backpay liability is limited to employers, these courts reason, the ADEA's must be as well. A careful analysis of the FLSA itself illustrates that this interpretation is unjustified.

\section{A. The Context of the FLSA}

The FLSA was a pro-labor New Deal measure passed in the aftermath of the NLRA. ${ }^{47}$ Concerned that industry hostility would obstruct the widespread organization of labor, Congress had sought through the NLRA to encourage collective bargaining and thereby protect the welfare of the working class. The FLSA, enacted three years after the NLRA, extended the earlier statute by establishing a minimum wage and maximum hour limit to benefit employees of certain industries. ${ }^{48}$

${ }^{45}$ Hearings on S 830 and S 788 before the Subcommittee on Labor (statement of Andrew J. Biemiller, AFL-CIO) (cited in note 23).

${ }^{46}$ See note 3 and accompanying text.

17 See 29 USC $\S 151$.

18 The FLSA was the third in a series of pro-labor statutes, the first being the NorrisLaGuardia Act of 1932, 29 USC $\$ \S 101-115$ (1982) (prohibiting the use of injunctions to forbid peaceful collective action) and the second being the NLRA. 
Supporters of the FLSA claimed that it would serve two purposes. First, it would extend the benefits of collective bargaining to the lowest class of workers who did not have the ability to organize. ${ }^{49}$ Second, the bill would preserve the progress unions had achieved by protecting employers who had negotiated with labor to eliminate unfair wage competition. ${ }^{50}$

The FLSA was not designed to aid wage earners who were themselves capable of negotiating for adequate working conditions. In fact, $\S 5$ of the original bill expressly exempted collective bargaining agreements from its scope. ${ }^{51}$ Senator Walsh, a primary sponsor of the bill, stated, "This bill is not concerned about wage earners that can protect their rights through collective bargaining. It excludes them from its provisions. It is only the lowest unprotected and unorganized wage earner that it seeks to protect from exploitation." ${ }^{\text {"52 }}$ Given the stated purposes of the statute, it made sense that only employers could be held liable under the FLSA. Its provisions were inapplicable to unions.

Following the passage of the FLSA, organized labor gained in strength. ${ }^{53}$ Realizing that a powerful union could restrict employees' rights as well as protect them, Congress passed a series of laws designed to curb potential union abuse. ${ }^{34}$ And when Congress began passing anti-discrimination legislation in the 1960's, the enactments explicitly covered unions as well as employers. In 1963, for example, Congress amended the FLSA with the Equal Pay Act ("EPA"), which prohibited unions and employers from discriminating on the basis of sex in the payment of wages. Title VII of the

49 Fair Labor Standards Act, S Rep No 75-884, 75th Cong, 1st Sess 3-4 (1937) (statement of Sen Black); 81 Cong Rec 7799 (July 29, 1937) (remarks of Sen Walsh).

${ }^{\text {so }} \mathrm{S}$ Rep No 75-884 at 7; 81 Cong Rec at 7800.

s1 S Rep No 75-884 at 7 .

s2 81 Cong Rec at 7800 .

83 Unions demonstrated their strength after World War II by disrupting the economy through a wave of strikes resulting in the loss of a record number of man-days. These strikes provided the impetus for regulatory legislation. See Russell A. Smith, et al, Labor Relations Law 38-40 (Michie, 7th ed 1979).

st The first statute passed was the Labor Management Relations Act of 1947, 29 USC $\S \S 141-169,171-197$. The LMRA, unlike the NLRA, adopted a neutral stance toward labor organizations. The statute protected the employee's right to refrain from collective activities as well as to participate in them. 29 USC $\$ 157$. The LMRA also outlawed certain union activities such as secondary boycotts, 29 USC $\$ \$ 158(\mathrm{~b})(4)(\mathrm{A})-(\mathrm{B})$, and jurisdictional strikes, 29 USC $\$ 158(b)(4)(D)$. In 1959, Congress passed the Labor Management Reporting and Disclosure Act. ("LMRDA"), 29 USC $\$ 401-531$ (1982), which regulated the internal affairs of unions and established a "bill of rights" for union members.

ss 29 USC § 206(d). 
Civil Rights Act of $1964^{56}$ proscribed union discrimination on the basis of race, color, religion, sex, or national origin. ${ }^{57}$ Finally, the ADEA, with substantive provisions mirroring those of Title VII, prohibited unions from engaging in age discrimination. ${ }^{58}$

The historical development of the labor movement suggests that the FLSA was not applied to unions because of their weakness at the time the statute was drafted. By the time the ADEA was passed, union power had increased considerably, and their capacity for abuse had grown accordingly. Thus, unlike the FLSA, the ADEA was drafted to handle misconduct by unions as well as employers. Courts that confine monetary liability under the ADEA to the employer liability provided by the FLSA ignore the growth in union power that occurred in the intervening years, and that the ADEA was partly meant to address.

\section{B. The EPA as an Analogy for the ADEA}

The EPA and ADEA are both amendments to the FLSA, and both prohibit discriminatory conduct by unions. Cases and commentary on union liability under the EPA provide valuable analogies for consideration of union liability under the ADEA. ${ }^{59}$

The EPA prohibits labor organizations from causing or attempting to cause an employer to discriminate in the payment of wages against any employee on the basis of sex..$^{60}$ Like the ADEA, it is enforced in accordance with the remedial provisions of the FLSA. Although the EPA contains no specific provisions for direct suits by employees, it does allow the government to recover damages from unions and distribute the money to the affected employees. ${ }^{61}$

The legislative history of the EPA indicates that Congress intended unions to be financially responsible for statutory violations. During the House debates on the statute, it was observed that "if a union . . . is in any way at fault in maintaining a discriminatory wage rate, [it] should be subject to all the penalties [provided in]

${ }^{\circ B} 42$ USC 2000 e et seq (cited in note 11).

${ }^{87} 42$ USC $2000 \mathrm{e}-2(\mathrm{c})(2)$.

ss 29 USC § 623(c).

${ }^{\circ 8}$ Commentary on the Equal Pay Act includes: Note, Remedies Against Unions Under the Equal Pay Act: The Role of the Court, 31 Md L Rev 365 (1971); Nancy R. Heinen, Union Liability for Discrimination in Collective Bargaining Agreements After Northwest Airlines, 5 Harv Women's L J 143 (1982); Note, Union Liability for Sex Discrimination, 23 Hastings L J 295 (1971); Riccucci, 65 U Detroit L Rev 379.

Bo 29 USC § 206(d)(2). The ADEA contains a similar provision. See 29 USC § 623(c). 61 29 USC $\S \S 206(d)(3), 216(c)$. 
the [FLSA]." "62 The draftsmen inserted the union liability provision after industry leaders pointed out that unions often negotiated differential wage rates. ${ }^{63}$ The leaders had pointed to the unions' role in negotiating pay differentials in the hopes that differentials included in collective bargaining agreements would be made statutorily exempt; they argued that since workers relied on unions to determine what provisions were in their best interest, a union-negotiated wage differential must be acceptable to the statutorily protected class. Congress rejected this suggestion, drafting the statute so as to place an affirmative obligation on unions to change existing agreements and to negotiate future contracts in accordance with the EPA. ${ }^{64}$

Considering the purpose of the EPA and its proponents' advocacy of union liability, inclusion of the Act within the pro-labor FLSA might seem puzzling. But the legislative history provides an answer-Congress wanted to employ an existing bureaucracy to administer its new Act. Congress would later use a similar rationale to justify the inclusion of the ADEA within the FLSA. Because the Wage and Hour Division in the Department of Labor was familiar with wage laws, and both industry and affected employees had dealt with the procedures of the Division regularly, compliance with the EPA was expected to be facilitated.$^{65}$ And though engrafting the EPA on the FLSA clouded the issue of union liability under the Act, Congress did not address the matter itself, leaving it to the courts instead. ${ }^{66}$

The Supreme Court has never decided whether a union can be held liable for monetary damages in an action brought by an employee under the EPA. ${ }^{67}$ While some lower federal courts have

${ }^{82}$ Summary of Remarks by Rep. O'Hara in Bureau of National Affairs, Equal Pay for Equal Work: The Federal Equal Pay Act of 196322 (1963) (emphasis added) (available remedies include employee wage suits, wage suits and injunction actions by the Secretary of Labor, and criminal actions by the Justice Department for willful violations).

${ }^{63}$ Id at 64-67.

84 109 Cong Rec 8698 (1963) (remarks by Reps O'Hara and Goodell).

6s Id. See generally, Note, 23 Hastings $L J$ at 300 (cited in note 59) (discussing Congress's belief, in enacting the EPA, that as an amendment to the FLSA the statute would be the "easiest and most efficient course of action," and noting that inclusion of the act within the FLSA undermined much of the EPA's effectiveness).

${ }^{66}$ See generally Note, 23 Hastings L J at 310 (cited in note 59). See also note 62 (legislators assumed that employees would have full range of FLSA remedies available to them in suits against unions; they did not expressly recognize any potential problems under the FLSA).

${ }^{67}$ The Court specifically refused to decide this issue in Northwest Airlines, Inc. $v$ Transport Workers, 451 US 77, 88-89 n 20 (1981). 
barred union liability under the Act, ${ }^{68}$ in Hodgson v Sagner, Inc. ${ }^{69}$ the Fourth Circuit affirmed a District Court decision holding a union jointly and severally liable for backpay under the EPA. The union in Sagner had negotiated a sexually discriminatory wage differential. The next year, when the employer agreed to correct the disparity, the union insisted that only a quarter of the remedial funds go to the female employees, and that the remainder be paid to the male employees as a general pay increase. The union's plan effectively perpetuated the discriminatory wage disparity. The District Court held that the union's actions proved its intent to discriminate, noting that the causal connection between the union's conduct and the discrimination was clear. Based on these facts, the court concluded that the union could be held liable for damages in the form of backpay. ${ }^{70}$

In determining union liability, the Sagner court did not undertake a detailed analysis of the remedial provisions of the FLSA. Instead, it held that it had the equitable power to order this relief despite the absence of an express mandate in the EPA. ${ }^{71}$

The result in Sagner is supported by the EPA interpretive regulations issued by the Department of Labor:

It is our opinion that the [EPA], in requiring that no labor organization, or its agents, ... "shall cause or attempt to cause such an employer to discriminate against an employee in violation of the equal pay provisions," is indicative of the legislative intent that the elimination of the wage rate differentials based on sex ... is a joint responsibility held by the union or unions with the employer. ${ }^{72}$

Sagner is valuable precedent for ADEA plaintiffs seeking damages from unions. ${ }^{73}$ While in that case the court based union

${ }^{68}$ See, for example, EEOC v Ferris State College, 493 F Supp 707 (W D Mich 1980); Murphy v Miller Brewing Co., 307 F Supp 829 (E D Wis 1969).

${ }^{89} 462$ F2d 180 (4th Cir 1972) (affirming Hodgson v Sagner, Inc., 326 F Supp 371 (D Md 1971)).

70 326 F Supp at $376-77$.

71 Id at 373-74.

72 Opinion Letter No 1187 of the Wage and Hour Administration (July 1, 1971), quoting 29 USC \& 206(d)(2)), cited in Brennan v Emerald Renovators, Inc., 410 F Supp 1057, 1060 n 6 (S D NY 1975). The Department does not always act consistently with these regulations. In Sagner, the Secretary of Labor asked the court to find the union jointly liable for damages, but one year later in Hodgson v School Board, 56 FRD 393 (W D Pa 1972), the government objected (unsuccessfully) to joinder of a union as a co-defendant on the grounds that the union would not be punished if found liable.

${ }^{23}$ The language of the opinion is broad, but the case could be narrowly construed to apply only to particularly egregious union conduct. If limited to its facts, Sagner may be 
liability on equitable principles invoked sua sponte, the ADEA expressly permits the use of equitable principles in fashioning relief for statutory violations. ${ }^{74}$ Thus, a court could point both to Sagner and to the ADEA's broad remedial language to support granting monetary relief against a union.

Moreover, as the exclusive statutory remedy for age discrimination, the ADEA presents an even stronger case for liberal construction than the EPA provisions interpreted in Sagner. The EPA's prohibition on sex discrimination is independently reinforced by Title VII, which explicitly provides for assessing backpay against unions. ${ }^{75}$ Thus, a plaintiff who is unsuccessful in recovering from a union under the EPA may turn to Title VII for relief. The ADEA, by contrast, is the exclusive statutory remedy for age discrimination, ${ }^{76}$ and the case for liberal construction of remedial provisions is compelling when injured plaintiffs possess no alternative statutory routes to recovery.

\section{Federal Labor Law: The Union's Duty of Fair REPRESENTATION}

Twenty years before Congress began enacting employment discrimination statutes, the Supreme Court recognized that unions might abuse their position as the sole representative of employees. In 1944, in Steele $v$ Louisville \& Nashville Railroad Co., ${ }^{77}$ the Court fashioned the duty of fair representation as a means of holding unions accountable for discriminatory practices. If an employee could prove that she was injured by her union's breach of this duty, she was entitled to monetary relief from the union.

The duty of fair representation and the ADEA serve a common goal-the protection of employee rights. Currently, however, unions that discriminate on the basis of age are held financially responsible for their actions only under the duty of fair representation. This incongruity is disturbing. It not only reduces the protection available to employees, but also forces age discrimination

valid precedent for ADEA plaintiffs only when the union has acted in extreme bad faith.

74 29 USC \& 626(b).

${ }^{26} 42$ USC $\$ 2000 \mathrm{e}-5$ (g).

${ }^{76}$ The following cases involve unsuccessful attempts by plaintiffs to bring age discrimination claims under Title VII or 42 USC $\$ 1983$ (1982): Ring $v$ Crisp County Hospital Authority, 652 F Supp 477 (M D Ga 1987) ( 1983 claim); McCroan v Bailey, 543 F Supp 1201 (S D Ga 1982) (§ 1983 claim); Frye v Grandy, 625 F Supp 1573 (D Md 1986) ( 1983 and Title VII claims); Morgan v Humboldt County School District, 623 F Supp 440 (D Nev 1985) ( $\$ 1983$ and Title VII claims).

${ }^{77} 323$ US 192 (1944). 
plaintiffs to fit their suits into the procedural and substantive framework of the duty of fair representation. This and the following section explore the ramifications of the disparity between union liability under the two areas of law.

A. The Standard for Union Conduct Under the Duty of Fair Representation

When first articulating the duty of fair representation in Steele, ${ }^{78}$ the Supreme Court found the duty implicit in the provisions of the Railway Labor Act ("RLA")

Unless the labor union representing a craft owes some duty to represent non-union members of the craft, at least to the extent of not discriminating against them as such in the contracts which it makes as their representative, the minority would be left with no means of protecting their interests or, indeed, their right to earn a livelihood .... The fair interpretation of the statutory language is that the organization chosen to represent a craft is to represent all its members, the majority as well as the minority, and it is to act for and not against those whom it represents. ${ }^{80}$

In Steele and other early decisions developing the duty of fair representation doctrine, ${ }^{81}$ the Court was disturbed by the unions' apparently racial motives for acting against black workers in collective bargaining groups. These cases illustrate that discriminatory conduct by unions spurred the Court's development of the duty of fair representation.

The Court developed the doctrine further in Ford Motor Company $v$ Huffman, ${ }^{82}$ and for the first time applied it outside the area of race discrimination. In.Huffman, the Court stated that the bargaining representative "owes complete loyalty to ... the interests

78 Id.

7945 USC $\S \S 151-188$ (1982). In Wallace Corp. $v$ Labor Board, 323 US 248 (1944), a case decided the same day as Steele, the Court suggested that the same duty of fair representation could be based on $\$ 9(a)$ of the NLRA. The Court officially recognized that the NLRA imposed this duty in Ford Motor Corp. $v$ Huffman, 345 US 330 (1953).

80 323 US at 201-02. In Steele, the Court compared the union's duty in negotiating a collective bargaining agreement to that of a legislature in the act of governance, holding that the union must fairly represent all its constituents.

'See Tunstall v Brotherhood of Locomotive Firemen, 323 US 210, 213 (1944) (union alleged to have stripped black plaintiff of seniority rights because of race).

82345 US 330 (1953) (Court found valid a seniority provision in a collective bargaining agreement that gave some seniority credit for pre- and post-employment military service). 
of all whom it represents."8s The Court qualified this expansive language, however, by giving the union wide discretion, subject only to "complete good faith and honesty of purpose."

The Court expanded the fair representation doctrine further in Conley $v$ Gibson. ${ }^{85}$ In Conley, the union had refused to help wrongfully discharged black employees prepare their grievances. The Court held that the union's duty to fairly represent employees applies through all phases of the labor relationship ${ }^{86}$ and that, consequently, the union is obliged not only to negotiate but also to administer a collective agreement fairly and without discrimination.

The Court finally enunciated a complete standard for the duty of fair representation in Vaca $v$ Sipes. ${ }^{87}$ The union in Vaca terminated an employee's grievance before entering final arbitration. The employee charged the union with arbitrary action, but the Court disagreed, finding that the union acted reasonably in settling the grievance before proceeding to time consuming arbitration. ${ }^{88} \mathrm{In}$ holding for the union, however, the Court bolstered the position of subsequent plaintiffs by broadening the duty of fair representation to preclude not only discriminatory or bad faith actions, but arbitrary conduct as well. ${ }^{89}$

Since Vaca, the Supreme Court has vacillated on the duty of fair representation standard. It narrowed the Vaca standard somewhat in Motor Coach Employees $v$ Lockridge ${ }^{90}$ to proscribe only intentional and severe union conduct. ${ }^{91}$ However, in Hines $v$ Anchor Motor Freight, Inc., ${ }^{82}$ the most recent case addressing the

ss Id at 338.

s4 The Court noted: "A wide range of reasonableness must be allowed a statutory bargaining representative ...." Id.

${ }^{85} 355$ US 41 (1957).

86 Id at 46.

s7 386 US 171 (1967).

ss Id at 192-93.

so See id at 190. The court noted elsewhere: "[T]he duty of fair representation has stood as the bulwark to prevent arbitrary union conduct against individuals stripped of traditional forms of redress by provisions of the federal labor law." Id at 182.

20403 US 274 (1971).

-1 The plaintiff in Lockridge brought an action for damages against the union for its role in the employee's wrongful discharge pursuant to a union security clause. Building on the "bad faith" prong of the Vaca standard, the Court stated that the plaintiff must present "substantial evidence of fraud, deceitful action or dishonest conduct." Id at 299 (quoting Humphrey $v$ Moore, 375 US 335, 348 (1964)). The Court then refused to find the labor officials' misrepresentation of the union contract a breach of the duty of fair representation, although such behavior was arguably "arbitrary" under Vaca.

${ }^{92} 424$ US 554 (1976). 
duty of fair representation standard, the Supreme Court disregarded the restrictive language of Lockridge and returned to Vaca's emphasis on arbitrary union conduct. ${ }^{93}$ The case also illustrates a shift from using the duty of fair representation to facilitate collective bargaining to using it to protect individual workers' rights against union abridgement.

Although the Vaca "arbitrary, discriminatory, or in bad faith" standard remains the law, the continual shifts in Supreme Court doctrine concerning the type of conduct that constitutes a breach of the union's statutory duty have left the lower courts with little guidance. ${ }^{94}$ Certain standards are clear, however. Courts hold unions to a less rigorous standard of conduct in negotiating a collective bargaining agreement than in administering the agreement. ${ }^{95}$ Courts justify this lower standard by noting that unions must be able to compromise in order to establish an agreement with the employer. ${ }^{96}$ Such a compromise may involve subordinating the rights of individuals within the bargaining unit to achieve the maximum possible benefit for the unit as a whole.

The standard governing union conduct in the administration of a collective agreement is more stringent. ${ }^{97}$ Vaca allows the union

93 In Hines the plaintiff-employees brought an action against the union, charging that it had breached its duty of fair representation in failing adequately to investigate the employer's charges against them. The Supreme Court upheld the claim, stating: "[E]nforcement of the finality provision where the arbitrator has erred is conditioned upon the union's having satisfied its statutory duty fairly to represent the employee in connection with the arbitration proceedings." 424 US at 571 . Hines may provide a basis for formulating the duty of fair representation in negligence terms-a subject that has generated much scholarly commentary. See David L. Gregory, Union Liability for Damages after Bowen v Postal Service: The Incongruity Between Labor Law and Title VII Jurisprudence, 35 Baylor L Rev 237, 255 n 102 (1983) (citing numerous articles on the subject).

94 In Ruzicka v General Motors Corp., 649 F2d 1207 (6th Cir 1981), a Sixth Circuit panel interpreted the "bad faith" prong of Vaca to require a finding of intentional misconduct. Other courts have used the apparent elasticity of the term "arbitrary" to hold unions liable for varying degrees of negligence. See, for example, Robesky $v$ Qantas Empire Airways Ltd., 573 F2d 1082, 1086-88 (9th Cir 1978); de Arroyo v Sindicato De Trabajadores Packing, AFL-CIO, 425 F2d 281, 284 (1st Cir 1970); Baldini v Local U. No. 1095, 581 F2d 145, 151 (7th Cir 1978).

${ }^{85}$ Clyde W. Summers, The Individual Employee's Rights Under the Collective Agreement: What Constitutes Fair Representation?, $126 \mathrm{U} \mathrm{Pa}$ L Rev 251, 254-57 (1977).

${ }^{2}$ Huffman, 345 US at 338 ("A wide range of reasonableness must be allowed a statutory bargaining representative ...."). An example of a court allowing a union to exercise wide discretion during negotiation is Bartman v Allis-Chalmers Corp., 799 F2d 311, 316 (7th Cir 1986).

${ }^{87}$ See Foust v IBEW, 572 F2d 710 (10th Cir 1978), rev'd on other grounds, 442 US 42 (1979) (court found breach of duty when union negligently failed to file an employee's grievance in a timely manner); Robesky, 573 F2d 1082 (union's reckless failure to notify an employee that her grievance would not be taken to arbitration was breach of duty); de Arroyo, 425 F2d 281 (union's failure to investigate grievance was a breach despite allegations of good 
to terminate individual grievances only if such decisions are made in good faith and without discriminatory intent. Hines further limits the discretion of unions by prohibiting gross errors of judgment in the processing of individual employees' grievances.

Supreme Court doctrine in this area, as outlined above, reflects a fundamental tension between two competing concerns: the need to protect the individual worker against discrimination by her union and the desire to facilitate collective bargaining between unions and employers for the good of employees as a group. This tension may have had an effect on lower courts applying the fair representation doctrine. Courts discuss the importance of protecting the individual employee, but the outcomes of cases reflect judicial deference to union decisions that adversely affect isolated workers. $^{98}$ This deference places a heavy burden on employee-plaintiffs in duty of fair representation actions and decreases the likelihood of recovery. ${ }^{99}$ The significance of this heavy plaintiff's burden for interpretation of the age discrimination statute will be discussed in a later section of this comment. ${ }^{100}$

\section{B. Union Liability for Breach of the Duty of Fair Representation}

Wallace Corp v Labor Board ${ }^{101}$ and Ford Motor Company $v$ Huffman ${ }^{102}$ established the right of the individual worker to bring suit against her union for breach of the duty of fair representation under $\S 9(a)$ of the National Labor Relations Act. ${ }^{103}$ The worker can sue her employer under $\S 301$ of the Labor Management Relations Act ${ }^{104}$ if the employer discriminated against her and breached the collective bargaining agreement. ${ }^{105}$

faith). See generally Julia Penny Clark, The Duty of Fair Representation: A Theoretical Structure, 51 Tex L Rev 1119 (1973); Paul H. Tobias, A Plea for the Wrongfully Discharged Employee Abandoned by His Union, 41 U Cin L Rev 55 (1972).

98 Michael J. Goldberg, The Duty of Fair Representation: What the Courts Do in Fact, 34 Buff L Rev 89 (1985).

'Id. See also Comment, The Union's Duty of Fair Representation-Fact or Fiction, 60 Marq L Rev 1116, 1116-17; Comment, Section 301 Employee Remedies and the Duty of Fair Representation: The Growing Need to Protect Individual Employee Rights, 11 Southern U L Rev 87, 96 (1985); Paul H. Tobias, The Plaintiff's View of "301-DFR" Litigation, 5 Emp Rel L J 510, 521 (1979-80).

${ }^{200}$ See notes $136-37$ and accompanying text.

102323 US 248 (1944).

202345 US 330 (1953).

${ }^{103} 29$ USC § 159(a).

104 29 USC $\S \S 141-69,171-97$ (1982).

105 Smith v Evening News, 371 US 195 (1962) (holding that an individual employee could bring suit against an employer under $\S 301$, toppling the dominant view that only unions could bring suit under the statute). 
In Humphrey $v$ Moore, ${ }^{108}$ the Supreme Court endorsed the view that an employee could simultaneously bring an action against the employer for breach of contract and against the union for breach of its duty of fair representation under $\S 301$ of the LMRA. However, the plaintiff-employee would have to prove a breach by the union of its duty of fair representation before collecting from the employer for breach of contract. ${ }^{107}$ In the early duty of fair representation cases, the employee sought damages from the union. In Conley $v$ Gibson, ${ }^{108}$ for example, the employees alleged wrongful conduct by the union and the employer, but sought damages only from the union. The Court held the union responsible for its own actions, and treated employer liability as an independent issue. ${ }^{108}$ The opinion did not address the issue of apportionment of damages between the employer and the union when their joint actions discriminated against individual employees.

After Conley, the lower courts generally held unions and the employers jointly and severally liable for discriminatory negotiation and administration of collective agreements. ${ }^{110}$ In Vaca, the Supreme Court held that liability for damages should be apportioned in relation to the respective fault of the parties:

The governing principle . . . is to apportion liability between the employer and the union according to the damage caused by the fault of each. Thus, damages attributable solely to the employer's breach of contract should not be charged to the union, but increases if any in those damages caused by the union's refusal to process the grievance should not be charged to the employer. ${ }^{111}$

In the end, this principle means that the bulk of damages (usually backpay) is paid by the employer who has triggered the lawsuit by

${ }^{108} 375$ US 335 (1964).

${ }^{107}$ In his Humphrey concurrence, Justice Goldberg clarified the source of a duty of fair representation/\$301 suit, explaining that a suit against a union is not based on $\S 301$ of the LMRA but on $\S 9(a)$ of the NLRA. Section 301 does not provide jurisdiction for independent fair representation suits, but it does allow a court to hear a fair representation claim annexed to a breach of contract action brought against an employer. 375 US at 351 .

${ }^{108} 355$ US 41 (1957).

109 Id at 45.

${ }^{110}$ See, for example, Richardson $v$ Texas And New Orleans Railroad Co., 242 F2d 230, 236 (5th Cir 1957); Hiller v Liquor Salesmen's Union Local No. 2, 338 F2d 778, 779 (2d Cir 1964); Cunningham v Erie Railroad Co., 243 F Supp 571, 576 (S D NY 1965), affd, 358 F2d 640 (2d Cir 1966).

111386 US at $197-98$. 
wrongfully discharging the employee. The Vaca Court emphasized that the union's conduct and the discharge by the employer were separate actions; the union had not colluded with the employer to discriminate against the employee or caused the employer to wrongfully discharge him. The Court suggested that if the union had done so, joint and several liability would have been proper. ${ }^{112}$

Two criticisms have been made of the Vaca apportionment approach. Some commentators have noted that the Vaca standard is based on a narrow view of causation. ${ }^{113}$ By emphasizing the discharge, the standard ignores the dynamics of the collective bargaining process. Discharge is only the first step in an employee's permanent termination, and a union's action after discharge can significantly affect whether an employee remains terminated. Thus, a union can often be a greater cause of termination than the Court recognized. ${ }^{114}$ Second, the Vaca standard, as construed by the Court in a later case, ${ }^{115}$ does little to deter egregious union conduct. ${ }^{116}$ Malicious unions are not punished to any greater extent than negligent ones.

The Vaca causation principle in particular has proved difficult for the lower federal courts to apply. ${ }^{112}$ When the Supreme Court encountered the apportionment issue in Hines $v$ Anchor Motor Freight, ${ }^{118}$ the majority opinion glossed over it, but a concurrence by Justice Stewart provided some much needed guidance. ${ }^{119}$ Jus-

132 Id at $197 \mathrm{n} 18$.

11 See, for example, Comment, Apportionment of Damages in DFR/Contract Suits: Who Pays for the Union's Breach, 1981 Wis L Rev 155, 175-76.

${ }^{114}$ See id. The Court modified the Vaca apportionment principle in Czosek v O'Mara, 397 US 25, 29 (1970), where in dictum it stated that the employer would be solely liable for lost backpay if it acted independently of the union in discharging the worker. The Court reasoned that the employer is the contractual obligor and the union's only duty is statutory. The union's breach of its duty required the employees to hire outside counsel to bring an action against the employer. Therefore, the union should be liable for employees' attorneys' fees and court costs only, not for contractual damages such as backpay. Critics of the Czosek standard note that it does not deter egregious union conduct. Comment, A Proposal for Apportioning Damages in Fair Representation Suits, 14 U Mich J L Ref 497, 509-12 (1981); Comment, 1981 Wis L Rev at 177-79 (cited in note 113).

${ }^{115}$ Czosek, 397 US 25 (union that had discriminatorily refused to process employee's grievance held liable for attorney's fees and court costs only; employer, as contractual obligor, is liable in full for backpay).

${ }^{116}$ Comment, $14 \mathrm{U}$ Mich J L Ref at 509-12 (cited in note 114); Comment, 1981 Wis L Rev at 177-79 (cited in note 113).

${ }^{217}$ Compare de Arroyo, 425 F2d at 281 (court holds employer solely liable for backpay unless the plaintiff can demonstrate that the union participated in the wrongful discharge), with Ruzicka $v$ General Motors Corp., 523 F2d 306 (6th Cir 1975), vacated and remanded, 649 F2d 1207 (damages split evenly between union and employer).

118424 US 554 (1976).

110 424 US at 572-73 (Stewart concurring). 
tice Stewart used a chronological causation analysis, explaining that the employer is liable for all damages caused by its breach of contract up to the point that the employee would have been reinstated but for the union's breach of its statutory duty. The union is liable for the employee's lost wages dating from its breach. Justice Stewart's approach provides increased deterrence for union misconduct, although critics believe it ignores the realities of fair representation litigation. ${ }^{120}$ Since a union breach typically occurs a short time after discharge, the union will generally be responsible for the bulk of the damages. For a union that acted only negligently, Stewart's methodology may amount to punitive damages.

The Supreme Court's most recent word on apportionment of liability in a duty of fair representation/\$ 301 suit came in Bowen $v$ United States Postal Service. ${ }^{121}$ In Bowen, the Court embraced the causation analysis set forth in Justice Stewart's Hines concurrence and held the union liable for the increase in damages caused by its failure to responsibly represent the employee. The employer remained secondarily liable for the damages attributed to the union. The Court emphasized that the primary concern in a duty of fair representation/\$301 suit should be full compensation of the injured employee. ${ }^{122}$ The Bowen opinion illustrates that the Court is willing to impose substantial monetary liability on unions guilty of discriminatory conduct under the fair representation doctrine.

The Supreme Court's suggestion in Vaca that federal courts fashion appropriate remedies for breach of the duty of fair representation $^{\mathbf{1 2 3}}$ has led to a variety of remedial awards. The principal award in these actions is compensation for lost wages, although courts also regularly award attorney's fees and court costs as well as injunctive relief. ${ }^{124}$ When reinstatement is not feasible, the courts occasionally award prospective relief for lost future earnings. ${ }^{125}$ Finally, while some plaintiffs have been compensated for

${ }^{120}$ See Comment, 14 U Mich J L Ref 497 (cited in note 114); Bowen v United States Postal Service, 459 US 212, 239 (1983) (White dissenting).

121459 US 212.

122 Id at $223 \mathrm{n} 12$.

123 Vaca, 386 US at $197 \mathrm{n} 18$.

${ }^{124}$ See Soto Segarra $v$ Sea-Land Service, Inc., 581 F2d 291, 298 (1st Cir 1978) (awarding employee-plaintiff backpay and attorney's fees); Central of Georgia Railway Co. $v$ Jones, 229 F2d 648 (5th Cir 1956) (awarding backpay and injunctive relief); Milstead $v$ International Bro. of Teamsters, $580 \mathrm{~F} 2 \mathrm{~d}$ 232, 237 (6th Cir 1978) (authorizing award of attorney's fees); Bowen v United States Postal Service, 470 F Supp 1127, 1132 (W D Va 1979) (authorizing award of court costs). See Comment, Breaching the Duty of Fair Representation: The Union's Liability, 17 John Marshall L Rev 415, 424 n $42-47$ (1984).

${ }^{125}$ See Bowen, 470 F Supp at 1131. 
mental distress, such awards are not common. ${ }^{126}$

In International Brotherhood of Electrical Workers $v$ Foust, ${ }^{127}$ the Supreme Court held that punitive damages are never appropriate in duty of fair representation suits, expressing concern that large jury verdicts could bankrupt unions. This limitation, however, decreases the courts' ability to fashion remedies that will provide maximum deterrence for egregious union conduct.

In sum, federal labor law holds unions fully responsible for their discriminatory conduct. In a duty of fair representation action, unions are generally held liable for discrimination against employees in a bargaining unit. If a union has participated in the negotiation of a discriminatory collective bargaining agreement, the courts will hold the union jointly and severally liable for all damages. In addition, if a union has failed faithfully to administer a labor agreement, the courts will impose liability from the time the union's breach "causes" continuing employee damages. Once the union is found liable, it must pay damages, generally in the form of backpay.

The evolution of the fair representation doctrine illustrates the Court's recognition that discriminatory actions by unions can seriously affect a worker's ability to make a living. Thus, the Court is concerned both with fully compensating victims of discrimination and with deterring union misconduct.

\section{The Relationship Between the Duty of Fair Representation and the ADEA}

The doctrine of the duty of fair representation and the ADEA are related in that they proscribe the same types of union behavior. This relation is not coincidental: the substantive provisions of the ADEA were modeled on those of Title VII, which were modeled on the NLRA, the statutory basis for the duty of fair representation. ${ }^{128}$ Thus, behavior violative of the ADEA often may

128 See Farmer v ARA Services, Inc., 660 F2d 1096, 1107 (6th Cir 1981) and de Arroyo, $425 \mathrm{~F} 2 \mathrm{~d}$ at 293 (both awarding damages for pain and suffering/mental damages). But see Soto Segarra, 581 F2d at 297-98 (damages for mental suffering can only be awarded in egregious cases; federal labor policy does not favor extreme damage awards).

${ }^{127} 442$ US 42 (1979).

${ }^{128}$ Franks v Bowman Transport Co., Inc., 424 US 747, 769 (1976) (NLRA forbids employers to differentiate among classes of employees without justification). See also US EEOC $v$ County of Calumet, 686 F2d 1249 (7th Cir 1982) (ADEA subordinates the principle of majority rule in the bargaining unit to the individual's right to be free from age discrimination; ADEA can be read to require the implicit insertion of a "no age discrimination" clause in labor contracts). 
also violate the duty of fair representation, and the two avenues stand as concurrent remedies for aggrieved plaintiffs. The Supreme Court has said that injured employees may simultaneously pursue all available avenues of relief for discriminatory conduct. ${ }^{129} \mathrm{How}$ ever, they can be fully compensated only once for any single discriminatory act. ${ }^{130}$

Federal courts construing the ADEA have recognized the relationship between the fair representation doctrine and the ADEA. In Bartman $v$ Allis-Chalmers Corp. ${ }^{131}$ the plaintiffs alleged that the union and employer had violated the ADEA by "forcing" employees to retire under threat of reduced benefits if they chose to remain employed. The court first analyzed the claim under the ADEA and then noted that the conduct pleaded in the complaint could constitute a breach of the union's duty of fair representation as well. The court proceeded to analyze the claim under the fair representation doctrine, although the plaintiffs had not explicitly alleged a violation of the duty of fair representation. ${ }^{132}$

This close relationship between the duty of fair representation and the ADEA suggests that union conduct which violates both should be similarly treated under the two doctrines. Similar treatment would produce a desirable synergy between federal labor law and the federal age discrimination statute, since the two areas of jurisprudence share comparable goals.

In each of the cases referred to in the introductory section of this comment, ${ }^{133}$ the plaintiffs claimed that the union had discriminated against them in violation of the ADEA. The alleged behavior of the union in each case would also constitute a breach of the duty of fair representation, although none of the plaintiffs included this claim in their complaints. In ALPA vTWA, the court found that the employer and the union violated the ADEA by modifying the labor agreement to include an age-based promotion policy that discriminated against pilots nearing retirement age. Similarly, in EEOC $v A L P A$, the Court held that the union and the employer violated the ADEA by agreeing to a contractual provision that gave 60 year-old pilots less favorable vacation benefits than younger pilots. The plaintiffs in Neuman $v$ Northwest Airlines, Inc. claimed that the union and the carrier negotiated and signed a contract

\footnotetext{
129 Alexander $v$ Gardner-Denver Co., 415 US 36 (1974).

${ }^{130}$ See Bowe $v$ Colgate-Palmolive Co., 416 F2d 711, 715 (7th Cir 1969).

191 799 F2d 311 (7th Cir 1986).

132 Id at 315.

133 See notes 3-5 and accompanying text.
} 
requiring the retirement of flight deck crew members at age 60 in violation of the ADEA.

In each of these cases, the union's behavior, if proven, would constitute a breach of its duty to fairly represent the employees in its bargaining units. Although the Supreme Court has stated that the union can exercise wide discretion in negotiating a labor contract, this discretion is constrained by the requirements of good faith and a lack of discriminatory motive. ${ }^{134}$ Union conduct violating the ADEA would not be free of discriminatory motivation and would therefore also constitute a breach of the duty of fair representation.

Had these cases been brought under the fair representation doctrine, the unions would have been liable for at least half of the plaintiff's backpay in each. ${ }^{135}$ In two of the cases, however, the courts refused to impose liability on the unions because the actions were brought under the ADEA rather than the duty of fair representation. ${ }^{138}$ In short, it was the label put on the employee's claim-not the union's culpability-that determined the union's financial liability. ${ }^{137}$

Troubling consequences result from the courts' inconsistent treatment of union discrimination under the ADEA and the fair representation doctrine. First, the incongruity encourages employees to circumvent the ADEA enforcement regime, which was specifically designed to encourage conciliation and informal proceedings in resolving age discrimination problems. ${ }^{138}$

Because courts have been more inclined to award damages against unions in suits brought under the duty of fair representation, employees suffering from union conduct actionable under ei-

1s4 Huffman, 345 US at 330. Lower federal courts have held that unions cannot bargain away employees' rights to bring age discrimination claims. See County of Calumet, 686 F2d at 1249.

${ }^{135}$ See text accompanying notes $120-22$.

${ }^{138}$ See ALPA $v$ TWA, 713 F2d at 940; Neuman, 28 FEP Cases (BNA) at 1488.

${ }^{137}$ In Boiero v Cuyahoga County Public Library Union, 1988 US Dist LEXIS 9266 (N D Ohio), the plaintiff-employee did not claim that the union had negotiated a discriminatory contract, but rather that the union refused to take her grievance to arbitration because of her age and national origin. The court held that these actions, if proven, would violate the ADEA and would support holding the union financially responsible. The union's conduct would also violate the duty of fair representation because federal labor law holds the union to a stringent standard in processing the grievances of injured employees. See Hines, 424 US at 554. When a union contributes to the damage of a wrongfully discharged employee by maliciously refusing to process the employee's grievance, Bowen requires the union to compensate the employee for the wages lost subsequent to the breach. See Bowen, 459 US at 212.

138 See text at note 14. 
ther doctrine are encouraged to bypass the ADEA and bring a duty of fair representation action, thereby increasing their chances of gaining monetary relief from the union. A plaintiff in a duty of fair representation action, however, is not required to notify the EEOC before proceeding. ${ }^{139}$ Thus, in their narrow reading of union liability under the ADEA, courts frustrate the conciliatory processes deemed important to addressing age discrimination at the time of the passage of the ADEA. The second unfortunate consequence of the inconsistent application of the duty of fair representation and the ADEA is a possible decrease in the deterrence of age discrimination.

A potential plaintiff has two choices. She can bring an action under the ADEA and risk the court's refusal to assess monetary damages against the union. Alternatively, she can bring a duty of fair representation action and risk dismissal for failure to satisfy the heavy evidentiary burden placed on plaintiffs in such actions.

Despite the stringent standards imposed on union conduct under the duty of fair representation, courts tend to favor union defendants in fair representation suits in order to facilitate collective bargaining. ${ }^{140}$ As one commentator has noted, "[P]laintiffs still face a lonely, uphill, and losing battle in court ... . [T]he ultimate outcome [of duty of fair representation suits] is generally defeat for the employees."141 Under either alternative, the union's age discrimination goes undeterred, and the injured plaintiff remains uncompensated. These results are incompatible with the purposes of the ADEA.

Victims of age discrimination should be encouraged to bring private actions under the ADEA in order to deter discriminatory conduct. Although Congress emphasized the desirability of conciliatory efforts by the Secretary of Labor to eliminate age discrimination, it also recognized the necessity of private enforcement and

${ }^{130}$ The employee may, however, be required to exhaust union grievance procedures before bringing the duty of fair representation suit. Glover $v$ St. Louis-San Francisco Railway Co., 393 US 324, 329 (1969); Republic Steel Corp. v Maddox, 379 US 650, 652 (1965). Courts generally make exceptions to this threshold requirement when the plaintiff shows that the union procedures would be ineffective. Clayton $v$ International Union, United Auto Workers, 451 US 679, 685 (1981); Glover, 393 US at 331; Vaca, 386 US at 185. Courts will also allow a plaintiff alleging a breach of the duty of fair representation during the negotiation stage of the collective agreement to bring the action without exhausting internal procedures. See Steele, 323 US at 206; Farmer, 660 F2d at 1106.

${ }^{140}$ See Goldberg, 34 Buff L Rev 89 (cited in note 98) (a study of duty of fair representation actions demonstrating that plaintiffs win in less than 5 per cent of the cases filed).

${ }^{141}$ Tobias, 5 Empl Rel L J at 523 (cited in note 99). 
explicitly provided for it in the ADEA. ${ }^{142}$ Section 7 of the ADEA requires only that the injured employee notify the Secretary before initiating a lawsuit, ${ }^{143}$ not that she go through an agency proceeding instead of a court action.

The experience of the Department of Labor in the years following passage of the ADEA demonstrates that private lawsuits are necessary to ensure deterrence of age discrimination. Statistics compiled by the Department indicate that the vast majority of age discrimination cases are not resolved by conciliation. ${ }^{144}$ The Secretary (and now, the EEOC) makes only a limited number of conciliation attempts, and an even smaller number of cases are successfully settled by the agency. Thus, Congressional belief in the necessity of private enforcement of the ADEA was well-founded, and courts should enact Congress's prescience by ensuring that successful plaintiffs receive full compensation from all parties guilty of age discrimination. Absent such a purposive interpretation, the ADEA will not be fully effective in decreasing age discrimination.

\section{Finding a Cause of Action Against Unions Under the ADEA}

No court that has faced the issue of union liability for damages under the ADEA has given the question the careful consideration it deserves. Courts denying union liability have rigidly interpreted the "amounts owing" provision in $\S 7(b)$ of the ADEA ${ }^{145}$ to require full incorporation of $\S 16(\mathrm{~b})$ of the FLSA, which limits liability to employers. This construction of the Act ignores the selective incorporation notion advanced by Congress. It also ignores the difference in the purposes of the two statutes and, as a result, hinders the effectuation of the ADEA's objectives.

Courts imposing monetary liability on unions have cited the broad remedial provision in $\S 7(\mathrm{~b})$ as the basis for their decision. ${ }^{146}$ This interpretation of $\S 7$ is a defensible reading of the text, but it

14229 USC $\$ 626(\mathrm{~b})$.

14329 USC \& 626(d).

14 Department of Labor, Age Discrimination in Employment Act of 1967: A Report Covering Activities Under the Act During 1976 (1977), cited in Vazquez v Eastern Airlines, Inc., 579 F2d 107, 111 (1st Cir 1978). This study shows that only 32 per cent of the cases pursued by the agency were resolved through conciliation. However, the majority of cases were not pursued by the agency, so the percentage of total cases resolved by conciliation is actually much lower than 32 percent.

165 See text at note 18.

148 See text accompanying note 24 . 
leaves the courts open-ended discretion to fashion limitless remedies under the Act. Neither approach produces an analytical framework that adheres to the text, comports with the legislative history, and furthers the purposes of the statute. This section attempts to formulate such an approach.

\section{A. Selective Incorporation of FLSA Remedies}

The "amounts owing" provision in $\S 7(\mathrm{~b})$ of the ADEA need not be read to require wholesale incorporation of $\S 16(\mathrm{~b})$ of the FLSA. Instead, the provision can be construed to require the selective incorporation of the FLSA's limited remedies into the ADEA. The remedies specified in the FLSA- "unpaid minimum wages and unpaid overtime compensation"- only compensate the plaintiff for economic losses. The FLSA does not allow other compensatory damages, such as relief for pain and suffering. Thus, the ADEA's selective incorporation of the FLSA remedies can be interpreted to limit ADEA remedies to compensation for economic loss.

The broad remedial provision in $\S 7(\mathrm{~b})$ of the ADEA authorizes courts to grant such "legal or equitable relief as necessary to effectuate the purposes of the Act." ${ }^{147}$ However, this broad grant of power must be understood as circumscribed by the limitation on the type of damages available. ${ }^{148}$ With this limitation on the discretion of the courts to fashion relief under the Act, the broad remedial language in $\S 7(\mathrm{~b})$ can be read to authorize the assessment of damages against unions. The provision is no longer open-ended. Courts are limited to compensating plaintiffs for economic losses only, but they can require any party whose conduct is proscribed by the substantive provisions of the Act to pay for the pecuniary injuries they cause. This construction of the ADEA allows courts to effectuate its objectives while remaining faithful to the limitations it imposes on judicial remedial power.

Other provisions of $\S 7(\mathrm{~b})$ of the ADEA can be read consistent with this interpretation of the ADEA. For instance, the section also states: "The provisions of this Act shall be enforced in accordance with the powers, remedies, and procedures provided in sections $11(b), 16, \ldots$ and 17 of the [FLSA] $\ldots$ and subsection (c) of

147 29 USC $\S 626(\mathrm{~b})$.

${ }^{148}$ Koyen $v$ Consolidated Edison Co. of New York, 560 F Supp 1161, 1168 (S D NY 1983) ("The manifest purpose of this broad grant of legal and equitable power is to enable the courts to fashion whatever remedy is required to fully compensate an employee for the economic injury sustained by him."). 
this section."149 These sections of the FLSA describe the administrative procedures available to the Secretary and the private litigant in enforcing the statute. ${ }^{180}$ Section $7(\mathrm{~b})$ 's requirement that the ADEA be administered in accordance with these sections of the FLSA means only that the Secretary and the private plaintiff must follow the FLSA procedures; it does not mandate the application of the FLSA substantive restrictions on union liability to nonFLSA claims. ${ }^{151}$

A textual reading that emphasizes the procedural rather than substantive correlation between the FLSA and the ADEA is consistent with statements of Congressional intent. ${ }^{152}$ It takes the notion of "selective incorporation" seriously, freeing the ADEA from provisions of the FLSA that are incompatible with the context and objectives of the age discrimination statute. The following sections discuss several reasons why this construction of the ADEA is preferable to the interpretations articulated by the courts.

\section{B. Support for Selective Incorporation: ADEA Case Law}

Courts construing the ADEA have limited its remedial provisions to cover only economic loss. For example, every circuit that has addressed the availability of compensatory damages under the ADEA has refused to award damages for pain and suffering. ${ }^{153}$

This refusal makes sense for several reasons. First, as noted by the First Circuit in Vazquez v Eastern Air Lines, Inc. ${ }^{154}$ the remedial provisions of the FLSA do not authorize compensatory dam-

1429 USC § 626(b).

180 Section 11(b) of the FLSA authorizes the Secretary to use state and local agencies to administer the Act. 29 USC § 211(b). In addition to authorizing private actions, §16(c) describes the general power of the Secretary to bring actions to recover unpaid wages and to supervise the disbursement of the recovered wages to affected employees. 29 USC § 216(c). Section 17 gives district courts jurisdiction to issue injunctions restraining violations of the statute. 29 USC § 217.

${ }^{161}$ See Sagner, 326 F Supp at 371 (while construing the FLSA remedial provision in an EPA action, the court assessed damages against a union on the basis of its "equitable" powers to fashion effective remedies).

138 See text at notes $39-43$. See also Hearings on S 830 and S 788 before the Subcommittee on Labor at 24-25 (cited in note 23) (remarks of Sen Javits); id at 29 (remarks of Sen Smathers) (emphasizing Congress's desire to use an existing bureaucracy to administer the ADEA because industry and the agency were familiar with the procedures). Also compare 29 USC $\S 623$ (c) (substantive provision of ADEA) with 42 USC $\S 2000 \mathrm{e}-2$ (c) (substantive provision of Title VII applicable to labor organizations).

183 Johnson v Al Tech Specialties Steel Corp., 731 F2d 143, 146-48 (2d Cir 1984); Perrell v Financeamerica Corp., 726 F2d 654, 657 (10th Cir 1984); Fiedler v Indianhead Truck Line, Inc., 670 F2d 806, 809-10 (8th Cir 1982); Vazquez v Eastern Airlines, Inc., 579 F2d 107, 111-12 (1st Cir 1978).

1s4 579 F2d 107. 
ages for pain and suffering. In addition, the legislative history of the ADEA suggests that Congress intended to authorize compensation only for economic losses. ${ }^{165}$ Although Congress recognized the detrimental effect that age discrimination has on the mental health of its victims, it included no express remedy for pain and suffering. ${ }^{156} \mathrm{~A}$ final argument that courts have used in denying non-economic compensatory damages under the ADEA is that such awards might decrease the likelihood of conciliation, an important purpose of the Act. If an ADEA plaintiff is aware that a large award for pain and suffering may be available from the courts, she will be more likely to litigate than to go through the agency. ${ }^{157}$

The weight of authority holds that an ADEA plaintiff can recover "front pay" damages for future lost earnings when she has been the victim of discrimination and reinstatement is not feasible. ${ }^{158}$ The availability of such damages is also consistent with the ADEA's selective incorporation of FLSA remedies. First, a future damage award is compensation for an economic loss and thus authorized by the remedial provisions of the FLSA. Second, without the availability of front pay, employers could avoid the objectives of the ADEA by making reinstatement so unattractive that plain-

15s Congress has stated that "[Under the ADEA] 'amounts owing' contemplates two elements: First, it includes items of pecuniary or economic loss such as wages, fringe, and other job-related benefits. Second, it includes liquidated damages (calculated as an amount equal to the pecuniary loss)." HR Rep No 95-950, 95th Cong, 2d Sess 13 (1978).

${ }^{156}$ See Age Discrimination in Employment Hearings on HR 3651, HR 3768, and HR 4221 before the Subcommittee on Labor of the House Committee on Education and Labor, 90th Cong, 1st Sess at 403-04 (Aug 16, 1967) (statement of Charles Rowan, Fraternal Order of Eagles); id at 421-22 (statement of Rep Pepper). See also Department of Labor, The Older American Worker: Age Discrimination in Employment at 100-02. The text of the Act authorizes an award for lost wages and for an equal amount in liquidated damages in cases of willful violations of the statute. See note 22 for the rationale behind the liquidated damages provision. See also Stevenson v J.C. Penney Co., 464 F Supp 945, 948-49 (N D Ill 1979); Rogers v Exxon Research \& Engineering Co., 530 F2d 834, 840 (3d Cir 1977) (construing the ADEA in accordance with its history and refusing to compensate plaintiffs for pain and suffering).

${ }^{167}$ See Rogers, 530 F2d at 841 . But see Vazquez, 579 F2d at 111 (rejecting Rogers analysis because employer has less reason to conciliate if he knows the damages available to a successful plaintiff in litigation are limited to purely economic losses).

${ }^{168}$ Wildman v Lerner Stores Corp., 771 F2d 605, 614-16 (1st Cir 1985); Whittlesey $v$ Union Carbide Corp., 742 F2d 724, 726 (2d Cir 1984); Maxfield v Sinclair International, 766 F2d 788, 795-97 (3d Cir 1985); Smith v Office of Personnel Management, 778 F2d 258, 262 n 2 (5th Cir 1985) (dictum); Davis $v$ Combustion Engineering, Inc., 742 F2d 916, 922-23 (6th Cir 1984); Gibson v Mohawk Rubber Co., 695 F2d 1093, 1100 (8th Cir 1982); Cancellier $v$ Federated Department Stores, 672 F2d 1312, 1319 (9th Cir 1982); EEOC v Prudential Federal Savings \& Loan Association, 741 F2d 1225, 1232 (10th Cix 1984); O'Donnell v Georgia Osteopathic Hospital, Inc., 748 F2d 1543, 1551 (11th Cir 1984). 
tiffs would not request it. ${ }^{159}$ Thus, the prospective remedy is supported by the language in $\S 7(\mathrm{~b})$ of the ADEA allowing courts to grant such legal or equitable relief as is necessary to further the purposes of the Act.

The availability of the front pay remedy is one example of why Congress included the broad remedial language in $\S 7(\mathrm{~b})$. Compensation for "lost wages" under the ADEA can be much more complex than a backpay award under the FLSA. The broad remedial language ensures that "amounts owing" is not construed narrowly to prevent age discrimination victims from being fully compensated for all pecuniary losses, including items not easily characterized as "wages." Courts have used Congress's implicit authorization of a broad definition of "wages" to award ADEA plaintiffs prospective salary increases and bonuses. ${ }^{160}$ Courts will also include commission income in a backpay award if a plaintiff can establish entitlement with sufficient certainty. ${ }^{161}$ In addition, courts have awarded ADEA victims lost life insurance ${ }^{\mathbf{1 6 2}}$ and pension $^{\mathbf{1 6 3}}$ benefits. Finally, courts have included unrealized profits on employee stock option plans, the value of health insurance, accrued sick leave, and other fringe benefits in backpay compensation awards when the availability of such benefits is not overly speculative. ${ }^{164}$

The above list illustrates the utility of the broad remedial language in $\S 7(b)$. Congress realized that the kinds of economic losses resulting from ADEA violations would evolve over time, and the text of the statute allows the courts to deal effectively with changed circumstances and complex compensation schemes. The Vazquez court recognized this flexibility and advocated a twotiered approach for the determination of available remedies under the ADEA. ${ }^{168}$ First, the court should look to the express provisions

${ }^{160}$ Koyen, $560 \mathrm{~F}$ Supp at 1168-69.

${ }^{100}$ Taylor v Home Insurance Co., 777 F2d 849 (4th Cir 1985); Kolb v Goldring, Inc., 694 F2d 869 (1st Cir 1982).

${ }_{161}$ Goldstein v Manhattan Industries, Inc., 758 F2d 1435 (11th Cir 1985).

${ }^{162}$ Fariss v Lynchburg Foundry, 769 F2d 958 (4th Cir 1985).

${ }^{163}$ Loeb v Textron, Inc., 600 F2d 1003 (1st Cir 1979).

${ }_{104}$ Whittlesey v Union Carbide Corp., 35 FEP Cases (BNA) 1085, 1088-89 (S D NY 1983), aff'd, 742 F2d 724 (2d Cir 1984) (profits on stock option plans); Blackwell $v$ Sun Electric Corp., 696 F2d 1176, 1185-86 (6th Cir 1983) (value of health insurance); Alford $v$ City of Lubbock, 484 F Supp 1001, 1004-05 (N D Tex 1979), aff'd in part, rev'd in part, 664 F2d 1263 (5th Cir 1982) (accrued sick leave); Kolb, 694 F2d at 874 (employee expense account, clothing discount). See Blackwell, 696 F2d at 1185 for discussion of speculativeness (court did not allow recovery for greater prospective earnings because of expanded sales territory).

${ }^{165}$ Vazquez, 579 F2d at 112 (construing ADEA to proscribe damages for pain and suf- 
of the ADEA to determine whether they clearly cover the requested relief. If they do not, under the authority granted by the broad statutory language the court should ask whether the requested relief would further all of the purposes of the Act, including the preference for conciliation over litigation. ${ }^{166}$ If this second requirement is met, the court can grant the requested relief.

Thus, a survey of ADEA case law provides precedent for a purposive construction of the Act in determining the financial responsibility of unions for discriminatory conduct. The cases discussing the remedial provisions of the ADEA focus on finding the type of relief that accomplishes the objectives of the statute. ${ }^{167}$ The language borrowed from the FLSA is an important consideration in the courts' analyses, but it has not been deemed determinative. Since the ADEA's text does not clearly resolve the issue of union liability for damages, an interpretation that refers to the purposes and history of the Act is justified and perhaps required.

C. Further Support for Selective Incorporation: Legislative Histories

The legislative history of the ADEA provides strong support for the interpretation of $\S 7(b)$ advocated by this comment. As discussed earlier, the sponsors of the Act focused on the efficiency of using the FLSA's established bureaucracy to administer the age discrimination statute. ${ }^{168}$ The noted advantages were ease of administration and the familiarity of industry with the procedures of the FLSA. The construction of $\S 7(\mathrm{~b})$ of the ADEA proposed by this comment is consistent with the Congressional emphasis on the advantages of FLSA procedure, since it would require adherence to the procedural mechanisms included in the FLSA.

The proposed interpretation is also supported by statements in the legislative history expressing a preference for enforcement by conciliation. ${ }^{169}$ This construction of the Act allows a plaintiff to bring a private action against the union but limits the available remedies to compensation for pecuniary loss. The limited damages

fering but noting that the decision could change if the need for additional remedies became apparent).

$188 \mathrm{Id}$.

${ }_{187}$ Id; Rogers, 550 F2d at 834; Dean v American Sec. Ins. Co., 559 F2d 1036 (5th Cir 1977) (all denying non-pecuniary damages under the ADEA after analyzing whether the remedy would further the purposes of the Act).

${ }^{1 e 8}$ See notes 38-43 and accompanying text.

168 S Rep No 723, 90th Cong, 1st Sess 5 (1967) (committees emphasized conciliation and persuasion as means of enforcement). 
available under this reading of the Act do not significantly increase an employee-plaintiff's incentive to litigate rather than go through the administrative agency. ${ }^{170}$ The legislative history of the Equal Pay Act also supports the proposed construction of the enforcement provision of the ADEA. The history of the EPA indicates that Congress intended courts to assess damages against unions for statutory violations. ${ }^{171}$ The EPA is analogous to the ADEA for two reasons. First, the statutes have comparable substantive provisions which proscribe certain discriminatory conduct by unions and employers. Second, Congress passed both statutes as amendments to the FLSA out of concern for efficient enforcement and ease of administration. ${ }^{172}$

\section{Final Support: The Purposes and Context of the ADEA.}

The purposes of the ADEA and the importance of ensuring their effectuation through a thoughtful interpretation of the statute have been discussed throughout this comment. Congress enacted the ADEA to prohibit and deter arbitrary age discrimination, emphasizing the use of conciliation and persuasion where possible. ${ }^{173}$ The refusal of some courts to impose monetary liability on discriminatory unions does not further any of these purposes. In fact, to the extent it fails to deter union violations, it hinders accomplishment of the Act's objectives. Imposing financial responsibility on unions for their discriminatory conduct would cause unions to "internalize" the costs of their discrimination and would ensure that they assign adequate importance to the eradication of age discrimination in negotiating and administering a collective bargaining agreement. ${ }^{174}$

Imposing backpay liability on unions is not inconsistent with Congress's expressed preference for conciliation and persuasion as the means of enforcing the statute. Congress enacted the provision authorizing private enforcement actions as a necessary supplement to agency conciliation efforts. The availability of a backpay remedy

170 The availability of some sort of damages against a union will create an incentive for the union to conciliate with the employee rather than go through litigation. Unions have no apparent incentive to avoid litigation if there is no possibility of financial liability. See Vazquez, 579 F2d at 111 (applying a similar argument to employers).

${ }^{171}$ See note 62-64 and accompanying text.

${ }^{172}$ See notes 38-43, 65-66 and accompanying text.

173 See note 14 and accompanying text.

174 See Note, Union Liability for Employer Discrimination, 93 Harv L Rev 702 (1980) (a similar argument for holding unions liable for signing discriminatory collective bargaining agreements under Title VII). 
against the union is necessary to ensure full compensation to the injured plaintiff, and may actually decrease the possibility of a trial. Potential liability for monetary damages will give unions strong incentive to avoid trial and go through the conciliation process.

Moreover, while the ADEA expresses a preference for conciliation, in practice most cases have not been settled by this mechanism. ${ }^{175}$ Therefore, the overriding concern of the ADEA-eliminating age discrimination-will only be fully effectuated through private enforcement of the Act. Plaintiffs injured by unions will have far more incentive to enforce the substantive provisions of the statute if compensation for their economic losses is available. The proposed interpretation of the statute rectifies this problem by providing compensation to ADEA plaintiffs injured by unions, thus facilitating enforcement of the Act.

The proposed selective incorporation of FLSA remedies into the ADEA would also harmonize the language of the statute with its context. Courts that refuse to assess damages against unions under the ADEA ignore the different legislative purposes underlying the FLSA and ADEA. Labor unions were not included in the substantive provisions of the original FLSA because they were not part of the problem the FLSA was designed to redress. ${ }^{176}$ In contrast, Congress recognized that unions were part of the age discrimination problem and drafted the ADEA to cover union conduct. ${ }^{177}$ The different rationales behind the FLSA and ADEA militate against a wooden application of the remedial provisions of the FLSA to ADEA claims.

Finally, imposing damages on a union that has violated the ADEA harmonizes employment discrimination law and the duty of fair representation doctrine. The availability of union damages under the ADEA would make the statute the preferable alternative for employees victimized by union discrimination. Under either an ADEA action or a duty of fair representation suit, the union would be liable for backpay, attorney's fees, and court costs. An ADEA action, however, is less burdensome for plaintiffs, ${ }^{178}$ and aims directly at age discrimination. Thus, an interpretation of the ADEA that allows an assessment of damages against unions better protects the rights of workers to be free from arbitrary discrimina-

\footnotetext{
178 See note 144.

176 See notes 49-52 and accompanying text.

177 See notes 9-13 and accompanying text.

${ }^{178}$ See notes $140-41$ and accompanying text.
} 
tion-a shared goal of both employment discrimination law and the duty of fair representation doctrine.

\section{CONCLUSION}

The ADEA has been described with good reason as a "hybrid" statute. Incorporating language from a variety of enactments, the Act is not a model of legislative clarity. Given this textual ambiguity and the Act's status as an amendment to the FLSA, the ADEA must be read carefully and in accordance with its history and purposes.

This comment has argued that the rigid incorporation of all FLSA provisions, including the provision foreclosing damages against unions, is not warranted. It has proposed a reading of the text of the ADEA that emphasizes the "selective incorporation" of FLSA procedures into the Act, giving courts wide discretion to create remedies that will ensure plaintiffs full compensation for their pecuniary losses. This remedial flexibility is limited by the requirement that the relief awarded under the ADEA accord with the FLSA, compensating for economic damages only. Limited in this fashion, the authorization in the ADEA to grant remedies that will further the purposes of the Act justifies an imposition of financial liability on unions. 
